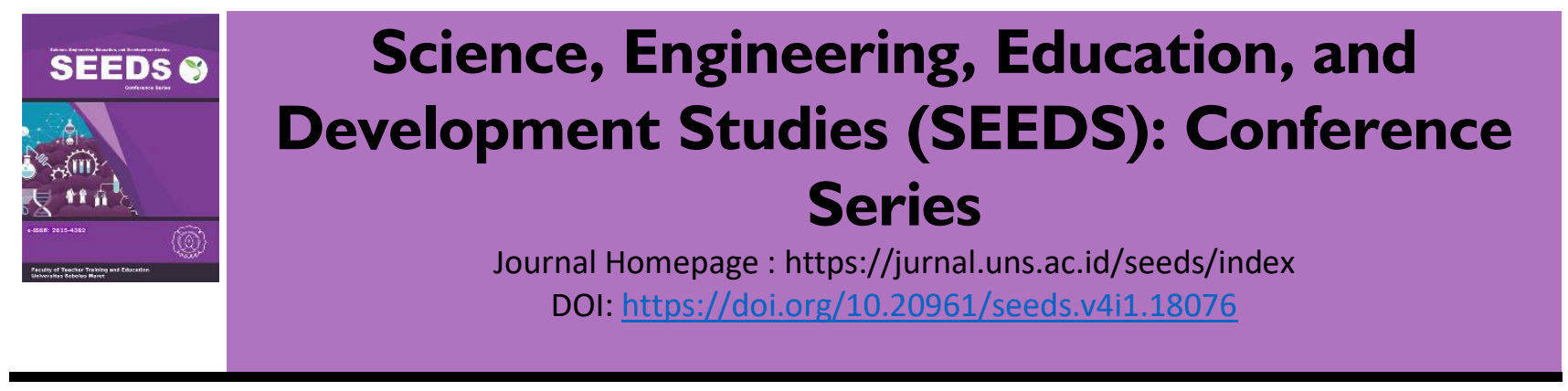

\title{
The Application of Jigsaw Cooperative Learning Model through Lesson Study in the Grade X of State Vocational High School/SMK in Sukoharjo
}

\author{
Ansheila Rusyda Subiyantari ${ }^{1}$, Abdul Haris Setiawan², Sri Sumarni ${ }^{3}$
} cbudiyanto@ymail.com

Article Info :

Available online $24 / 11 / 2021$

Keywords:

jigsaw cooperative

lesson study

participation

learning outcome

\begin{abstract}
Cooperative learning model Jigsaw which collaborated with lesson study is one of the strategies used to stimulate the students ' participation in the learning process, especially in solving and explaining each answer of problems given by the teacher so that the learning process is not only centered on the teacher but also the students. The purposes of this research are to: (1) determine the application of the appropriate steps in order to increase students' participation and students' learning outcome through Jigsaw cooperative learning model with lesson study; (2) to know the improvement of students' participation and students' learning outcome for the Engineering Mechanics subject of grade X of state SMK in Sukoharjo through the implementation of Jigsaw cooperative learning model with lesson study. This research is a classroom action research which conducted in three cycles.

The results showed that: (1) there was appropriate application of steps in improving the students' participation and students' learning outcome in accordance with the Jigsaw cooperative learning model through lesson study; (2) students became more active in participating in grade, such as asking, giving opinion, and discussion. The percentage of completeness of students' learning outcome in the cognitive area of precycle was $30 \%, 64.71 \%$ in the first cycle, $79.41 \%$ in the second cycle, and $82.35 \%$ in the third cycle. Then, in term of students' learning outcome in the affective area, most students were predicated Very Good and Good. Next, the percentage of completeness student learning outcome in the pre-cycle of psychomotor was $26.67 \%, 61.76 \%$ in the first cycle, $79.41 \%$ in the second cycle, and $85.29 \%$ in the third cycle. From this analysis, it can be concluded that the implementation of Jigsaw cooperative model through lesson study with appropriate steps has succesfully increased the students' participation and students' learning outcome of grade X of state SMK in Sukoharjo on the subjects of Engineering Mechanics..
\end{abstract}




\section{INTRODUCTION}

Jigsaw technique is one of the cooperative learning models supporting the students to be active and helpful with each order in mastering the lesson in order to gain maximum achievement. Edward (1989) in (Isjoni: 54). According to Zubaidah, et al. (2011), this cooperative method was developed by Elliot Aronson in Austin, Texas in 1978 as a response for the poor performance and low self-esteem of African-American children. This method then has been adapted widely and it can be used in various contexts.

Soni and Krismiyati (2014) conduct a research about the usage of Wifi Ad Hoc-based Jigsaw learning method towards the effectiveness of students in the case study at State Vocational High School 1 Tengaran. It points out that the application is proven in increasing student's activity. The learning process shows positive response from the students, it helps the students in receiving the materials, and it can attract the attention of the students. They also become more active and the class situation is settled better than the others with conventional method. The study outcome indicates a significant improvement of the pre-test and post-test.

In Qingdao University of Science and Technology, the students can develop interest in learning English, motivate, and encourage reading ability after using Jigsaw cooperative learning strategy. Moreover, this technique creates a student-centered learning. It can be said that the approach of this technique is effective to teach English reading in higher education level (Meng, 2010).

Lesson study is a collaborative learning improvement conducted by a group of teachers in curriculum cycle and learning, goal setting, planning of joint learning, application and observation of the implemented lessons (Lewis and Hurd, 2011). It is a school-centered collaborative activity for the teachers featured with careful, wise and thoughtful planning and responsive in improving a continuous cycle lesson (Laila, 2016). In a wide scale, it refers to a professional development process involving a small group of teachers who have different ability levels yet have interest to work together and special objective to design and perform the planned and examined lesson (Fong 2015). An alternative way to improve learning quality is by conducting lesson study since the learning study can be done collaboratively and continuously (Utami and Herry, 2011).

Deriving from the professional development approach of primary school teachers in Japan, lesson study has been applied in many countries including America (Murata, 2009) and Korea. The result of lesson study in Korea points out that subjects can be converted to a more specific learning objective for students, such as doing math assignment in an exact and meaningful way and designing lesson structure to maximize student's involvement. The teachers who participate in the importance of detailed lesson plan will realize about practice complexity and develop better understanding in using student's ideas (Pang, 2016).

The study of Utami and Herry (2011) shows that the achievement of Analytical Geometry II on semester III students, academic year 2011/2012, improved once the lesson study-based Numbered Heads Together (NHT) learning model was applied.

Teacher needs to be creative in making instructional media and choosing various methods. The classroom atmosphere can be livelier and the material can be absorbed by each student since Jigsaw and make-a-match learning methods are applied through open class lesson study on science and biology subjects (Sriningsih dkk, 2011). In 2016, Laila's research of lesson study in Filipina mentions that the technique improved the quality of math teachers and encouraged their professional development effectively. It helps them to understand students' way of thinking better. Besides, they also said that observing and analyzing other's lesson can help reflecting the lesson deeper, thus teacher can be more critical in choosing right learning model to help the students understand the lesson.

There is a problem on grade X students at State Vocational High School in Sukoharjo in which they are not active enough in asking question and giving feedback in the learning process of Engineering Mechanics. Furthermore, the passive students, who usually sit on the back, get less attention since the teacher will only focus on the active students.

From the explanation above, this research is conducted to identify the right steps of the implementation to improve student's participation and learning outcome with Jigsaw cooperative learning model through lesson study. This research also purposes to examine the increase of participation and learning outcome of Grade X students at State Vocational High School in Sukoharjo in Engineering Mechanics course. It is conducted by applying Jigsaw through lesson study. 


\section{METHOD}

This study belongs to Classroom Action Research with qualitative approach. It is conducted by the researcher, subject teacher, and observer team. The data collection techniques are observation, interview, document study, and test.

The gathered data is then tested for validity by using data triangulation for the observation, interview, document study, and test results. The applied data analysis method is interactive analysis model including data collection, reduction, presentation, and conclusion. The research procedure has cycle steps, including action planning and implementation, observation, and reflection.

\section{RESULT AND DISCUSSION}

The research subject is 34 students in Grade X. It is done from January to March 2017. The subject materials are calculating simple beam with centre and distributed load constructions and the Truss Force by using method of joints.

\section{A. Planning Step}

In this step, the research is collaborated with lesson study forming an observer team as its characteristic. The team is in charge of assist the teacher in discussing the learning plan in the Acting Step. An empirical study of Lee and Takahashi (2011) gives analytical description of interactive process via learning plan, including realizing, leading to the conclusion that the class teacher uses learning plan as communicative source in identifying problem, determining the assumption of the teaching, and taking action for the possible developed class interaction.

Planning per cycle is conducted with the observer team. The researcher and the observer make a concept map of the detailed activity for Acting and Observing Step. The map consists of:

1. Making research instruments, including:

a) Syllabus

b) Learning Implementation Plan

c) Questions and answers for group discussion

d) Questions and answers for individual test

e) Grading indicator points of student's participant observation and the affective and psychomotor domains

2. Determining the learning object and target

3. Preparing the media for learning process

The table below shows the planning result which has been conducted by the researcher and the observer in each cycle.

\begin{tabular}{|l|l|l|}
\hline \multicolumn{1}{|c|}{ Cycle I } & \multicolumn{1}{|c|}{ Cycle II } & \multicolumn{1}{c|}{ Cycle III } \\
\hline $\begin{array}{l}\text { Giving longer time for } \\
\text { student's discussion }\end{array}$ & $\begin{array}{l}\text { Students who are shy to ask } \\
\text { questions will get more } \\
\text { attention and the passive } \\
\text { students get questions as the } \\
\text { stimulus. }\end{array}$ & $\begin{array}{l}\text { Using video or equipment in } \\
\text { the learning process }\end{array}$ \\
\hline $\begin{array}{l}\text { The students with low } \\
\text { participation and competency } \\
\text { get more attention. }\end{array}$ & $\begin{array}{l}\text { Giving paper to the students } \\
\text { for making mind mapping to } \\
\text { understand the difference of } \\
\text { simple beam with centre and } \\
\text { distributed load constructions } \\
\text { better. }\end{array}$ & $\begin{array}{l}\text { Changing the student groups } \\
\text { on expert teams to make the } \\
\text { and slow-thinking } \\
\text { students separate equally }\end{array}$ \\
\hline $\begin{array}{l}\text { The student's participation } \\
\text { and learning outcome need to } \\
\text { be improved. }\end{array}$ & $\begin{array}{l}\text { The student's teamwork in } \\
\text { group discussion needs to be } \\
\text { improved. }\end{array}$ & $\begin{array}{l}\text { Giving longer time for } \\
\text { student's presentation }\end{array}$ \\
\hline
\end{tabular}




\begin{tabular}{|l|l|l|}
\hline $\begin{array}{l}\text { Having Jigsaw cooperative } \\
\text { learning model }\end{array}$ & $\begin{array}{l}\text { Changing the student groups } \\
\text { on expert teams to make them } \\
\text { quiet and focus more on the } \\
\text { teamwork. }\end{array}$ & \\
\hline
\end{tabular}

\section{B. Acting and Observing Step}

The researcher and observer conduct action according to the plan and monitor student's activity during the learning process.

1. Participation of Student

Table 1. The Achievement Predicate of Student Participation

\begin{tabular}{|cccccccccccccccccc|}
\hline Aspec & \multicolumn{4}{c|}{ Pre-Cycle } & \multicolumn{1}{c|}{ Cycle I } & \multicolumn{1}{c|}{ Cycle II } & \multicolumn{1}{c|}{ Cycle III } \\
ny & P & P & P & PS & PS & PS & P & P & P & P & P & P & PS & PS & PS & PS \\
& S & S & S & 1 & 4 & 3 & S & S & S & S & S & S & 4 & 3 & 2 & 1 \\
& 4 & 3 & 2 & & & & 2 & 1 & 4 & 3 & 2 & 1 & & & & \\
\hline A & 2 & 1 & 13 & 14 & 8 & 14 & 11 & 1 & 11 & 18 & 5 & 0 & 15 & 16 & 3 & 0 \\
B & 1 & 2 & 24 & 2 & 8 & 17 & 9 & 0 & 10 & 18 & 6 & 0 & 13 & 17 & 4 & 0 \\
C & - & - & - & - & 9 & 16 & 9 & 0 & 13 & 14 & 7 & 0 & 16 & 15 & 3 & 0 \\
\hline
\end{tabular}

Note:

Noted Aspects

$\mathrm{A}=$ Participation in Asking

$\mathrm{B}=$ Participation in Giving Opinion

$\mathrm{C}=$ Participation in Discussion

Participation of Student (PS)

PS 4 = Very Good, Score 4

PS $3=$ Good, Score 3

PS 2 = Adequate, Score 2

PS 1 = Deficient, Score 1

Before conducting the action, the researcher observes the students in Grade $\mathrm{X}$ and finds out that they do not participate actively during the learning process, especially in asking and giving opinion. When the teacher is explaining the lesson, the students who sit on the back make noise since they mostly do not get the teacher's attention. They also tend to be sleepy. When the teacher throws a question, they are passive and they do not answer or response. Furthermore, after the teacher explains the lesson material, there are only 2 students who ask questions while the others look shy to ask. Since many of the students are passive, it seems to be one-sided learning process. To be graded for participating, the students have to be active and practice how to discover, search, ask, analyze the possible answer, manage, and speak out the result communicatively (Suryosubroto, 2002).

Cycle I applies Jigsaw cooperative learning model with the teacher who splits groups. On the previous learning process, the students have not done the discussion with the technique yet, thus they seem to be more active. It is seen from how the students participate actively in asking about the subject that they do not understand. They also give more opinion and they are willing to solve problems on the whiteboard. They learn how to be responsible in doing the tasks and share them with the home teams group later. Each group member who does it can create more efficient and active learning, to the point they are mentioned for participating (Taniredja, 2010). During the discussion, the students ask and explain the lesson material with their group members. Here, the teacher has a role to monitor the discussion and help students who have problem.

Cycle II has an increase of student's participation since they start to participate actively in finishing the assignment and eager to answer question from the teacher. Besides, they also take part in explaining the material within the group and express their opinion in front of their friends. The students can participate actively when they can think critically of the opinion of others thus they can also give opinion and response (Taniredja, 2010). During presentation, the students are also more eager to be in front of the class. This is 
due to the teacher pays more attention to the less active students, thus the students who lack of understanding in Cycle I become more active and confident in Cycle II.

The change of expert team also affects the students positively as they become more active and confident in Cycle III. This matter is strengthen by the result of interview with them in which they state that the implementation of Jigsaw cooperative learning model through lesson study makes them can ask each other and discuss with group members. They also mention that they participate more actively because the learning process turns to be more comfortable and enjoyable. Moreover, the teacher says that less active students become more active and they understand the lesson better since they can work together. This matter is compatible with the research of Fitriasari and Nurdin (2012), in which the percentage of college students who ask questions increases from 79\% in Experiment I to 91\% in Experiment II. For the discussion, it increases from 78\% in Experiment I to 88\% in Experiment II after using Jigsaw cooperative learning model in Architecture and Computer Organization courses.

\section{Student Learning Outcome}

a) Cognitive Domain

Table 2. The Integrated Achievement of Student Learning Outcome in Cognitive Domain

\begin{tabular}{|llcccc|}
\hline No & \multicolumn{1}{c}{ Achievement } & \multicolumn{3}{c|}{ Amount of Students } \\
\cline { 3 - 5 } & & $\begin{array}{c}\text { Pre- } \\
\text { Cycle }\end{array}$ & Cycle I & Cycle II & Cycle III \\
\hline 1. & $\begin{array}{l}\text { Students who get } 78 \text { or } \geq 78 \\
\text { marks }\end{array}$ & 9 & 22 & 27 & 28 \\
2. & Students who get $<78$ marks & 21 & 12 & 7 & 6 \\
3. & Class Average & 63,07 & 79,94 & 83,21 & 84,82 \\
4. & Percentage of Completeness & $30 \%$ & $64,71 \%$ & $79,41 \%$ & $82,35 \%$ \\
5. & Percentage of Incompleteness & $70 \%$ & $35,29 \%$ & $20,59 \%$ & $17,65 \%$ \\
\hline
\end{tabular}

The student learning outcome in this domain has an increase compared with the Pre-Cycle by having 79,94 as the class average; $64,71 \%$ as the percentage of completeness and $35,29 \%$ for the incompleteness. There are still 12 students out of 34 who have not reached the minimum completeness criteria yet.

The student learning outcome in Cycle II has an increase compared with the Cycle I. The class average of Cycle II is 83,21 with $79,41 \%$ as the percentage of completeness and $20,59 \%$ as the percentage of incompleteness. This increase is due to the teacher gives paper to the students for making mind mapping, thus they can learn more about the difference of simple beam with centre and distributed load constructions.

For Cycle III, the student learning outcome shows an increase compared with the Cycle II. The class average is 84,82 ; the percentage of completeness is $82,35 \%$ and the percentage of completeness is $17,65 \%$. The application of Jigsaw cooperative learning model in this cycle is collaborated by providing equipment and video. The students who have difficulties in Cycle I and II then can understand the lesson more.

The employment of instructional media by teacher which can improve student learning outcome is inseparable from lesson study process. This process makes the teacher revise instructional media usage based on the reflection of the previous learning (Rokhmawati, 2011). The research of Gulsen Cagatay and Gokhan Demircioglu (2013) entitled "The Effect of Jigsaw-I Cooperative Learning Technique on Students' Understanding about Basic Organic Chemistry Concepts" results that the student group who gets Jigsaw model application have better result of post-test than the students with traditional teaching.

\section{b) Affective Domain}

The observed points in this domain include quietness, discipline, responsibility, teamwork, cooperation, tolerance, and activeness. 
Table 3. The Achievement Predicate of Student Participation in Affective Domain

\begin{tabular}{|c|c|c|c|c|c|}
\hline \multirow[t]{2}{*}{ No } & \multirow[t]{2}{*}{ Achievement } & \multicolumn{4}{|c|}{ Amount of Students } \\
\hline & & Pre-Cycle & Cycle I & $\begin{array}{c}\text { Cycle } \\
\text { II }\end{array}$ & $\begin{array}{c}\text { Cycle } \\
\text { III }\end{array}$ \\
\hline 1. & Students who get Very Good (VG) predicate & 2 & 4 & 6 & 9 \\
\hline 2. & Students who get Good $(\mathrm{G})$ predicate & 9 & 17 & 15 & 20 \\
\hline 3. & Students who get Adequate (A) predicate & 15 & 11 & 12 & 5 \\
\hline 4. & Students who get Deficient (D) predicate & 4 & 2 & 1 & 0 \\
\hline
\end{tabular}

In this domain, the Pre-Cycle has 2 students who get Very Good (VG) predicate, 9 students who get Good $(\mathrm{G})$ predicate, and 4 others who get Adequate $(\mathrm{A})$ predicate. There is an increase in Cycle I in which 4 students are predicated as Good (VG), 17 students as Good (G), and 2 students as Adequate (A).

Cycle II has an improvement since there are 6 students who are predicated as Very Good (VG) and 15 others have Good (G) predicate. Still, there is a student who is marked as Adequate. The next cycle also improves because there are 9 students receiving Very Good (VG) predicate, 20 students for Good $(\mathrm{G})$ predicate, and no student belongs to Adequate.

The connection of lesson study has a significant impact to improve teacher's performance in monitoring student's activity and discussing with the researcher and other teachers, too. The research of lesson study written by Widoretno, et al. (2010) in Biology points out the improvement of independence and teamwork qualities of college students. The positive effects of lesson study implementation on relevant research are teamwork and solidarity development for teaching team, easier class management, more development on college student's capability in the Affective Domain, and the improvement for the lacking component of learning process through the planning and application on next activity.

c) Psychomotor Domain

Table 4. The Integrated Achievement of Student Learning Outcome in Psychomotor Domain

\begin{tabular}{|clcccc|}
\hline No & \multicolumn{1}{c}{ Achievement } & \multicolumn{3}{c|}{ Amount of Students } \\
\cline { 3 - 6 } & Pre-Cycle & Cycle I & Cycle II & Cycle III \\
\hline 1. & $\begin{array}{l}\text { Students who get 78 or } \geq 78 \\
\text { marks }\end{array}$ & 8 & 21 & 27 & 29 \\
2. & Students who get $<78$ marks & 22 & 13 & 7 & 5 \\
3. & Class Average & 68,21 & 76,68 & 80,78 & 83,61 \\
4. & Percentage of Completeness & $26,67 \%$ & $61,76 \%$ & $79,41 \%$ & $85,29 \%$ \\
5. & Percentage of Incompleteness & $73,33 \%$ & $38,24 \%$ & $20,59 \%$ & $14,71 \%$ \\
\hline
\end{tabular}

This domain presents data for class average in Pre-Cycle which is 68,21; in which the percentage of completeness is $26,67 \%$. In the first cycle, the class average is 76,68 and the percentages is $61,76 \%$ for completeness and $38,24 \%$ for the incompleteness. The class average is 80,78 ; the percentage of completeness is $79,41 \%$; and the percentage of incompleteness is $20,59 \%$.

The class average in Cycle II raises from the Cycle I. Thus, this domain has reached the targeted indicators. The rising numbers are caused by the students who become better in drawing diagram and following the explained steps from the teacher. The learning outcome in Cycle III 
shows the increase of 83,61 in class average; in which the percentage of completeness is $85,29 \%$ and $14,71 \%$ for the incompleteness.

\section{Reflecting Step}

This step includes the report of learning application process of the researcher and the observer. Then, the result is examined and discussed together to find the answer thus the next cycle can be improved. The finding of learning process in each cycle is as follow :

\begin{tabular}{|l|l|l|}
\hline \multicolumn{1}{|c|}{ Cycle I } & \multicolumn{1}{|c|}{ Cycle II } & \multicolumn{1}{|c|}{ Cycle III } \\
\hline $\begin{array}{l}\text { The time for explaining the } \\
\text { lesson is too long and the } \\
\text { discussion time becomes less. }\end{array}$ & $\begin{array}{l}\text { Some students are still making } \\
\text { noise in class. }\end{array}$ & $\begin{array}{l}\text { The students are used to the } \\
\text { Jigsaw cooperative learning } \\
\text { model through lesson study. }\end{array}$ \\
\hline $\begin{array}{l}\text { Some students are shy to ask and } \\
\text { passive during discussion. }\end{array}$ & $\begin{array}{l}\text { There are students who still not } \\
\text { willing to work together in the } \\
\text { assignment of group discussion. }\end{array}$ & $\begin{array}{l}\text { The class condition is more } \\
\text { quiet and conducive. }\end{array}$ \\
\hline $\begin{array}{l}\text { Students answer the question } \\
\text { from teacher by following } \\
\text { others. }\end{array}$ & $\begin{array}{l}\text { The improvement of student's } \\
\text { participation is still insignificant. }\end{array}$ & $\begin{array}{l}\text { The change of expert teams } \\
\text { group makes the students put } \\
\text { more effort on teamwork in } \\
\text { solving the assignment. }\end{array}$ \\
\hline $\begin{array}{l}\text { Students are still confused in } \\
\text { distinguishing simple beam with } \\
\text { centre and distributed load } \\
\text { constructions. }\end{array}$ & $\begin{array}{l}\text { The students try to solve the } \\
\text { problem and answer teacher's } \\
\text { question actively. }\end{array}$ & $\begin{array}{l}\text { The students become more } \\
\text { responsible in solving group's } \\
\text { assignment. }\end{array}$ \\
\hline & $\begin{array}{l}\text { The teacher can pay more attention } \\
\text { to the less active students. }\end{array}$ & \\
\hline
\end{tabular}

The teacher evaluates the finding during discussion section by mentioning the real student's response on the research and examines how the finding can be revised from the discussion (Fujii, 2016). Warwick, et al. (2016) observes the teacher studying group discussion of teachers during the learning process through lesson study by searching the facts that teacher can learn something about teaching, the way students study, or the discussion of identification from the most productive researcher.

\section{CONCLUSION}

Based on the result of study and discussion above, it can be concluded that:

1. The application steps of Jigsaw cooperative learning model through lesson study accurately focusing on the selection of expert teams group combined with the use of mind mapping paper on simple beam construction subject and the use of equipment and video in calculating Truss Force by using method of joints subject are effective to improve student participation in asking and giving opinion and to give positive effect in improving student learning outcomes.

2. The application of Jigsaw cooperative learning model through lesson study can raise students' participation and learning outcomes in the cognitive, affective, and psychomotor domains in Engineering Mechanics course. 


\section{REFERENCES}

Cagatay, Gulsen \& Demircioglu, Gokhan. (2013). The Effect of Jigsaw-I Cooperative Learning Technique on Students' Understanding about Basic Organic Chemistry Concepts. Educational Research Association The International Journal of Educational Researchers 2013, 4 (2): 0-37 ISSN: 1308-9501.

Fitriasari, Novi Sofia \& Nurdin, Enjang Ali (2012). Meningkatkan Efektifitas Pembelajaran dan Prestasi Belajar Mahasiswa pada Mata Kuliah Arsitektur dan Organisasi Komputer dengan Metode Pembelajaran Jigsaw. Jurnal Pendidikan Teknologi dan Informasi ISSN:1979-9462.

Fong MW (2015) Effects of Lesson Study incorporating phase-based instruction on grade seventh students' geometry achievement. In: 7th ICMI-East Asia regional conference on mathematics education. Cebu City, Philippines.

Fujii, Toshiakira. 2016. Designing and adapting tasks in lesson planning: a critical process of Lesson Study. ZDM Mathematics Education (2016) 48:411-423 DOI:10.1007/s11858-016-0770-3.

Isjoni. (2014). Cooperative Learning Mengembangkan Kemampuan Belajar Berkelompok. Bandung : Alfabeta.

Lee, Y. A., \& Takahashi, A. (2011). Lesson plans and the contingency of classroom interactions. Human Studies, 34(2):209-227.

Lewis, C. C., \& Hurd, J. (2011). Lesson study step by step: How teacher learning communities improve instruction. Portsmouth: Heinemann.

Lomibao, Laila S. (2016). Enhancing Mathematics Teachers Quality through Lesson Study. Lomibao SpringerPlus (2016) 5:1590 DOI:10.1186/s40064-016-3215-0

Meng, Jing. (2010). Jigsaw Cooperative Learning in English Reading. ISSN 1798-4769 Journal of Language Teaching and Research, Vol. 1, No. 4, pp. 501 504, July 2010 ACADEMY PUBLISHER Manufactured in Finland. DOI:10.4304/jltr.1.4.501-504.

Murata, A. (2009). Individual and Group Learning Paths in Lesson Study. Notes for STRIDE conference, May 2009.

Murwaningsih, Utami \& Susanto, Herry Agus. (2011). Peningkatan Prestasi Belajar Geometri Nalitik Ii Melalui Model Pembelajaran Kooperatif Tipe Numbered Heads Together (NHT) Berbasis Lesson Study. Prosiding Seminar Nasional Lesson Study 4:183-192. ISBN 978-602-97895-5-3.

Pang, Jeongsuk. (2016). Improving mathematics instruction and supporting teacher learning in Korea through lesson study using five practices. ZDM Mathematics Education (2016) 48:471-483 DOI:10.1007/s11858-016-0768-x.

Rinawan, Soni Yanu \& Krismiyati. (2014). Efektivitas Penggunaan Metode Pembelajaran Jigsaw Berbasis Wifi Ad Hoc Dalam Pembelajaran Sistem Basis Data Kelas Xi Jurusan Rekayasa Perangkat Lunak (Studi Kasus SMKN 1 Tengaran). Jurnal Teknologi Informasi-Aiti, Vol. 11. No.2, Agustus 2014:101202.

Rokhmawati, Ana. 2011. Implementasi Praktik Pengalaman Lapangan Berbasis Lesson Study Untuk Meningkatkan Keterampilan Mahasiswa Dalam Memanfaatkan Media Pembelajaran. Prosiding Seminar Nasional Lesson Study 4:56-67. ISBN 978-602-97895-5-3.

Sriningsih, dkk. (2011). Pembelajaran IPA-Biologi dengan Perpaduan Metode Jigsaw dan Make A-Match pada Open Class Lesson Study di SMP Yapenas Gempol. Prosiding Seminar Nasional Lesson Study 4:359-367. ISBN 978-602-97895-5-3. 359-367. 
Suryosubroto, B. (2002). Proses Belajar Mengajar di Sekolah. Jakarta : Rineka Cipta.

Tracy \& Cathy. (2005). Improving Teaching through Lesson Study. Teacher Education Quarterly, Winter 2005.

Warwick, P., Vrikki, M., Vermunt J. D., Mercer, N., \& Halem, N. V. (2016). Connecting observations of student and teacher learning: An examination of dialogic processes in Lesson Study discussions in mathematics. ZDM Mathematics Education, 48(4) DOI:10.1007/s11858-015-0750-z.

Widoretno, dkk. (2010). Peningkatan Kualitas Kemandirian dan Kerjasama Mahasiswa Melalui Lesson Study Peserta Perkuliahan Ekologi Tumbuhan di Program Studi P. Biologi-P.MIPA-FKIP-UNS. Jurnal UNS E.058.

Zubaidah, S., Yuliati, L., dan Mahanal, S. (2011). Ragam Model Dan Metode Pembelajaran IPA. UM: program TEQIP (Teacher Quality Improvement). 